\title{
Pengaruh Organizational Justice terhadap Employee Engagement melalui Organizational Identification
}

\author{
Amelia Yuhana Prativi \\ Praptini Yulianti \\ Manajemen, Universitas Airlangga, Indonesia \\ Korespondensi penulis: amelia.yuvi@gmail.com
}

\begin{abstract}
This study uses objects in one of the state-owned companies engaged in microfinance services, namely PT Permodalan Nasional Madani (Persero) Investment Management. In this case, of course, PT PNM Investment Management has growth that is very dependent on the service of employees to customers. Therefore, companies must continually improve services to customers and be able to maintain and improve employee performance. This research aims to determine the effect of organizational justice on employee engagement through organizational identification. This quantitative study is based on data collected using a questionnaire distributed to 78 respondents of PT Investment Management is then analyzed using partial least square. In the results of the analysis using PLS, it was found that organizational identification was able to mediate the effect of organizational justice (distributive justice, procedural justice, interactional justice) on employee engagement. This shows that the employee engagement can be achieved by many factors and some of them are about the concept of justice applied by the company and identification of the organization owned by employees, especially employees of PT PNM Investment Management.
\end{abstract}

Keywords: Distributive justice; Employee engagement; Interactional justice; Organizational identification; Organizational justice; Procedural justice.

Abstract. Penelitian ini menggunakan obyek di salah satu perusahaan BUMN yang
bergerak di bidang jasa keuangan mikro, yaitu PT Permodalan Nasional Madani
(Persero) Invesment Management. Perusahaan memiliki pertumbuhan yang sangat ber-
gantung pada layanan para karyawan kepada nasabahnya. Oleh karena itu, perusahaan
selalu berupaya meningkatkan layanan kepada nasabah serta mempertahankan dan
meningkatkan kinerja karyawan. Penelitian ini bertujuan untuk mengetahui pengaruh
organizational justice terhadap employee engagement melalui mediasi organizational
identification. Penelitian ini menggunakan pendekatan kuantitatif yang didasarkan pada
data primer yang dikumpulkan melalui penyebaran kuesioner kepada 78 orang respon-
den, yaitu karyawan PT PNM Invesment Management. Selanjutnya, data dianalisis
menggunakan teknik partial least square (PLS). Hasil analisis menggunakan PLS
menemukan bahwa organizational identification mampu memediasi pengaruh organi-
zational justice, yang terdiri atas distributive justice, procedural justice, dan interact-
tional justice terhadap employee engagement. Hasil analisis tersebut menunjukkan 
bahwa employee engagement yang dimiliki karyawan mampu dicapai melalui banyak faktor. Di antara beberapa faktor tersebut adalah konsep keadilan yang diterapkan perusahaan dan identifikasi organisasional oleh karyawan PT PNM Invesment Management.

Kata Kunci: Identifikasi organisasi; Keadilan distibutif; Keadilan interaksional; Keadilan organisasional; Keadilan prosedural; Keterikatan karyawan.

Article Info:

Received: December 4, 2019 Accepted: September 4, 2020 Available Online: September 11, 2020 DOI: http://dx.doi.org/10.30588/jmp.v10i1.592

\section{LATAR BELAKANG}

Organizational justice dianggap faktor penting di dalam organisasi, karena teori keadilan menyatakan bahwa karyawan cenderung membandingkan rasio antara usaha atau kontribusi yang ia lakukan harus seimbang dengan hasil yang ia terima (Gibson, Donnelly, \& Ivanceivich, 2009). Kondisi tersebut akan berpengaruh pada employee engagement yang menjadi kontributor sangat penting bagi keberhasilan suatu perusahaan (Ayers dalam Pillai \& Asalatha, 2013). Pegawai yang engaged atau terikat tidak hanya akan memberikan kontribusi lebih, tetapi ia juga akan lebih loyal, sehingga kemungkinannya lebih kecil untuk meninggalkan organisasi secara sukarela (Macey \& Schneider, 2008). Employee engagement dipengaruhi oleh beberapa faktor di antaranya adalah kepemimpinan, kompensasi, iklim organisasi, pelatihan, dan kerja sama (Anitha, 2014).

Iklim organisasi yang baik dapat diciptakan melalui manajemen sumber daya manusia dengan memberikan fasilitas yang memadai dan memperlakukan karyawan secara adil dalam organisasi (Konovsky, 2000). Untuk mewujudkan hal tersebut, keadilan organisasi (organizational justice) diperlukan di dalam organisasi. Menurut Greenberg (dalam Noruzi, Westover, \& Rahimi, 2010), keadilan organisasional adalah sebuah konsep yang menunjukkan persepsi karyawan tentang sejauh mana mereka diperlakukan secara adil di dalam organisasi.

Penelitian Özer, Uğurluoğlu, dan Saygili (2017) menjelaskan tentang Effect of Organizational Justice, yaitu persepsi keadilan organisasi meningkat secara statistik dan signifikan terhadap keterlibatan kerja karyawan. Sehubungan dengan keterlibatan kerja, maka efek paling signifikan diciptakan oleh keadilan prosedural yang diikuti oleh keadilan distributif dan keadilan interaksional. Di sisi lain, penelitian oleh Alvi dan Abbasi (2012) menerangkan Impact of Organizational Justice on Employee Engagement yang menunjukkan bahwa keadilan memainkan peran penting dalam mempromosikan karyawan memiliki keterlibatan dalam organisasi perusahaan. Kedua penelitian terdahulu tesebut memperkuat keyakinan bahwa ada pengaruh yang cukup signifikan antara organizational justice terhadap employee engagement, sehingga adanya keadilan organisasi secara langsung akan memotivasi karyawan untuk lebih meningkatkan komitmen terhadap organisasi dan merasakan kepuasan dengan pekerjaan mereka. Kondisi tersebut akan meningkatkan keterlibatan kerja karyawan di dalam perusahaan. Pendapat ini diperkuat oleh Jansen, Kant, Nijhuis, Swaen, \& Kristensen (2004) yang menjelaskan tentang dampak keadilan organisasional, yaitu apabila karyawan diperlaku- 
kan dengan kompensasi yang baik serta adil, maka hal itu akan memotivasi dan mendorong karyawan untuk meluangkan waktu, energi, pengalaman dan pendidikan mereka dalam organisasi secara maksimal (Ahmed, Bwisa, Otieno, \& Karanja, 2014).

Menurut pendapat Gulluce dan Kahyaoglu (2016), keadilan prosedural, keadilan interaksional, dan keadilan distributif secara signifikan mampu memprediksi identifikasi organisasi. Hal ini menunjukkan adanya hubungan yang cukup kuat antara keadilan organisasi dan identifikasi organisasi. Keadilan organisasi adalah prediktor identifikasi organisasi, karena semakin tinggi persepsi keadilan, semakin tinggi pula tingkat identifikasinya. Semua sub-dimensi keadilan organisasi dapat memprediksi perilaku identifikasi organisasi dan keadilan prosedural menjadi prediktor terkuatnya. Prediktor signifikan lainnya dari identifikasi organisasi adalah keadilan interaksional, sedangkan keadilan distributif memiliki efek pada identifikasi organisasi pada tingkat yang lebih rendah (Terzi, Dülker, Altın, Çelik, Dalkiran, Yulcu, Tekin, \& Deniz, 2017).

Saat ini, fenomena yang sering terjadi di dalam perusahaan adalah kinerja karyawan yang cenderung mengalami penurunan akibat semakin banyaknya jumlah beban kerja yang mereka miliki, tetapi mereka memiliki keterbatasan kapabilitas meskipun jumlah tenaga kerja perusahaan sudah mencapai titik maksimal. Pada dasarnya, penambahan jumlah tenaga kerja tanpa diimbangi oleh penambahan kegiatan pelatihan dapat menyebabkan rawannya perlakuan ketidakadilan perusahaan pada karyawannya. Hal tersebut akan menyulitkan berkembangnya trust pada organisasi, kebanggaan sebagai anggota organisasi atau Organizational Identification (OID) dan employee engagement, sehingga kondisi tersebut akan menyebabkan penurunan kinerja karyawan. Penurunan kinerja karyawan ditandai oleh beberapa tugas atau pekerjaan yang belum dapat diselesaikan secara tepat waktu (Yulianti \& Puteri, 2016).

Dari uraian tersebut, tujuan penelitian ini adalah untuk mengetahui pengaruh organizational justice terhadap employee engagement melalui mediasi organizational identification. Keterbaruan penelitian ini terletak pada penggunaan variabel mediasi (intervening) untuk melihat pengaruh tiga persepsi keadilan karyawan dalam suatu organisasi melalui rumusan permasalahan penelitian ini, yaitu apakah komponenkomponen organizational justice berpengaruh terhadap employee engagement melalui organizational identification. Dalam konteks penelitian ini, komponen organizational justice terdiri atas distributive justice, procedural justice, dan interactional justice.

\section{KAJIAN TEORITIS}

\section{Keadilan Distributif (Distributive Justice)}

Keadilan distributif adalah sejauh mana rewards dan punishment diberikan karyawan terkait dengan kinerja (Riani, 2013). Persepsi keadilan distributif mempengaruhi kepuasan individu dengan berbagai pekerjaan yang berhubungan dengan hasil, seperti gaji, tugas kerja, pengakuan, dan kesempatan untuk lebih maju. Keadilan distributif adalah keadilan yang terkait jumlah dan pemberian penghargaan di antara individu (Robbins \& Judge, 2015:145). Aristotle menyebutkan bahwa keadilan distributif terdiri atas tiga indikator, yaitu keadilan, persamaan, dan kebutuhan. Keadilan merupakan tindakan menghargai karyawan berdasarkan kontribusinya (equity), sedangkan persamaan adalah upaya menyediakan kompensasi bagi setiap karyawan yang pada dasarnya 
sama (equality), dan kebutuhan merupakan penyediaan benefit atau manfaat berdasarkan kebutuhan personal (Cropanzano, Bowen, \& Gilliland, 2007).

\section{Keadilan Prosedural (Procedural Justice)}

Keadilan prosedural mengacu pada sarana pengalokasian hasil, tetapi tidak secara khusus pada hasil itu sendiri atau individu (Cropanzano et al., 2007). Keadilan prosedural menerapkan prinsip-prinsip untuk menentukan dan mengatur karyawan dalam proses pengambilan keputusan. Keadilan prosedural berfokus pada proses yang digunakan untuk membuat keputusan.

\section{Keadilan Interaksional (Interactional Justice)}

Keadilan interaksional merupakan keadilan yang paling sederhana di antara tiga macam keadilan yang dikaji dalam penelitian ini. Keadilan interaksional mengacu pada sejauh mana seseorang memperlakukan orang lain (Cropanzano et al., 2007). Di sisi lain, keadilan interaksional merupakan keadilan yang berhubungan dengan perlakuan dan penghargaan kepada karyawan oleh atasan (Colquitt, 2001).

\section{Keterikatan Karyawan (Employee Engagement)}

Keterikatan karyawan merupakan kontributor penting dalam upaya retensi karyawan, retensi dan kepuasan pelanggan, serta kinerja. Hal tersebut mengandung pengertian bahwa keterikatan karyawan merupakan salah satu faktor yang mendukung terciptanya keefektifan dan kinerja optimal dalam sebuah organisasi. Pada dasarnya, dimensi keterikatan karyawan menjabarkan aspek-aspek keterikatan (engagement), yaitu vigor (semangat) yang mencerminkan kesiapan untuk mengabdikan upaya dalam pekerjaan seseorang; dedication (dedikasi) yang ditandai oleh suatu perasaan penuh makna, inspirasi, dan kebanggaan; dan absorption yang ditandai ketika seseorang menjadi benarbenar tenggelam di dalam pekerjaan, penuh konsentrasi, dan minat yang mendalam terhadap pekerjaannya, sehingga waktu terasa begitu cepat dan individu sulit melepaskan diri dari pekerjaannya (Schaufeli, Salanova, González-romá, \& Bakker 2002).

\section{Identifikasi Organisasional (Organizational Identification)}

Cheney dan Tompkins (1987) menjelaskan bahwa identitas organisasi adalah persepsi atas perasaan memiliki seseorang untuk melakukan identifikasi diri dalam sebuah kelompok. Senada dengan Pratt dan Zeckhauser (1985), identifikasi organisasi atau OID adalah rasa satu kesatuan dengan organisasi. Dalam hal ini, sebuah koneksi kognitif muncul antara individu dan organisasi berupa sebuah proses, ketika keyakinan individu tentang organisasi mengacu pada dirinya sendiri. Karyawan dengan OID yang lebih tinggi cenderung menikmati peningkatan keterlibatan mereka dengan pekerjaan, karena mereka beranggapan bahwa hubungan antara kontribusi mereka dan organisasi, tempat mereka bekerja adalah saling menguntungkan (Reilly \& Brown, 2012).

\section{Pengembangan Hipotesis}

\section{Pengaruh Keadilan Distributif terhadap Identifikasi Organisasional}

Hasil penelitian Cheung dan Law (2008) menunjukkan bahwa keadilan distributif terkait langsung dengan identifikasi organisasional melalui dukungan persepsi organisasi. Hal itu menunjukkan bahwa keadilan distributif terkait informasi mewakili persepsi status antarkelompok (seperti mengirimkan informasi yang akurat atau menerima penjelasan yang masuk akal tentang prosedur pekerjaan di dalam kelompok yang sama) 
yang merupakan stimulus utama untuk mempromosikan kepada karyawan atas perasaan keterikatan psikologis mereka yang telah merasakan keadilan distribusi dalam bekerja. Atas dasar tersebut, hipotesis kesatu (H1) dirumuskan sebagai berikut:

\section{H1: Keadilan Distributif berpengaruh signifikan terhadap Identifikasi Organisa- sional.}

\section{Pengaruh Keadilan Prosedural terhadap Identifikasi Organisasional}

Keadilan prosedural berkaitan dengan prosedur-prosedur yang digunakan oleh organisasi untuk mendistribusikan hasil dan sumber daya organisasi kepada anggotanya. Organisasi yang bertindak adil dan dapat menumbuhkan emosi positif akan membuat anggotanya merasa mempunyai kewajiban untuk peduli terhadapnya, serta membantu organisasi mencapai tujuan dan mengarahkan anggota untuk menyatukan status peran ke dalam identitas sosialnya (Rhoades \& Eisenberger, 2002). Identifikasi organisasional merupakan kebanggaan karyawan terhadap perusahaannya. Mael dan Ashforth (1992) berpendapat bahwa karyawan yang memiliki identifikasi tinggi akan bertindak dari sudut pandang organisasi dan diperkuat oleh faktor yang menarik di mata mereka, sehingga hal itu dapat menumbuhkan emosi positif bagi karyawan (Herabadi, Verplanken, \& Knippenberg, 2009). Dari uraian tersebut, rumusan hipotesis kedua (H2) adalah:

\section{H2: Keadilan Prosedural berpengaruh signifikan terhadap Identifikasi Organisa- sional.}

\section{Pengaruh Keadilan Interaksional terhadap Identifikasi Organisasional}

Keadilan interaksional berhubungan dengan persepsi keadilan mengenai kualitas perlakuan pimpinan ketika mengimplementasikan kebijakan tertentu di dalam organisasi. Hal ini lebih fokus pada kondisi apakah seorang karyawan yang bekerja diperlakukan adil atau tidak. Apakah pengambil kebijakan menginformasikan dengan baik atau tidak, atau apakah pengambil kebijakan menyampaikannya dengan hormat atau tidak, merupakan hal-hal yang dapat menjelaskan keadilan interaksional (Kreitner \& Kinicki, 2007:244-245). Senada dengan kondisi tersebut, Terzi et al. (2017) menyatakan bahwa ada hubungan positif antara keadilan interaksional dan identifikasi organisasional. Dari uraian tersebut, maka rumusan hipotesis ketiga (H3) adalah:

\section{H3: Keadilan Interaksional berpengaruh signifikan terhadap Identifikasi Organi- sasional.}

\section{Pengaruh Keadilan Distributif terhadap Keterikatan Karyawan}

Keadilan distributif merupakan determinan utama untuk memprediksi kepuasan kerja karyawan, sehingga kepuasan kerja akan mempengaruhi kinerja karyawan (Fischer dalam Budiarto \& Wardani, 2005). Keadilan distributif merefleksikan persepsi keadilan dalam jumlah atau besaran penghargaan (reward) yang diberikan kepada karyawan. Penelitian sebelumnya menunjukkan bahwa sub-dimensi persepsi keadilan organisasional bersama-sama menjelaskan 33\% total varian. Dengan demikian, peningkatan persepsi keadilan organisasional meningkatkan keterikatan karyawan secara signifikan. 
Secara konseptual, keterikatan karyawan (employee engagement) yang tinggi dapat mempertahankan penerapan nilai-nilai perusahaan untuk menjalankan pekerjaan, sehingga keinginan untuk bekerja secara maksimal dapat tercapai dan keinginan untuk memajukan organisasi semakin besar melalui keadilan distributif (Özer et al., 2017). Atas dasar hal itu, hipotesis keempat (H4) dirumuskan sebagai berikut:

\section{H4: Keadilan Distributif berpengaruh signifikan terhadap Keterikatan Karya- wan.}

\section{Pengaruh Keadilan Prosedural terhadap Keterikatan Karyawan}

Keadilan prosedural menunjuk pada keadilan yang diterima dari cara dan proses yang digunakan untuk menentukan jumlah dan distribusi sumber daya (Colquitt, 2001). Penelitian yang dilakukan oleh Ghosh, Rai, dan Sinha (2014) menunjukkan bahwa keadilan distributif, prosedural, dan interaksional saling terkait dengan masing-masing dimensi keadilan organisasi, karena pengaruh persepsi keadilan pada berbagai macam hasil kerja merupakan hasil dari sebagian keterikatan karyawan. Dengan kata lain, ketika para karyawan memiliki persepsi yang tinggi tentang keadilan dalam organisasi mereka, maka mereka dipastikan merasa memiliki kewajiban untuk berlaku adil dalam memainkan peran mereka dengan cara memberi melampaui tingkat keterikatannya. Di sisi lain, persepsi keadilan yang rendah kemungkinan disebabkan oleh para karyawan yang menarik diri dan melepaskan diri mereka sendiri dari peran kerjanya. Keadilan merupakan salah satu kondisi kerja dalam model keterikatan. Berkurangnya keadilan dapat memperburuk kondisi burnout (kelelahan) karyawan, sedangkan persepsi positif keadilan dapat memperbaiki keterikatan mereka (Maslach et al, 2001 dalam Saks, 2006). Dari uraian tersebut, hipotesis kelima (H5) dirumuskan sebagai berikut:

\section{H5: Keadilan Prosedural berpengaruh signifikan terhadap Keterikatan Karya- wan.}

\section{Pengaruh Keadilan Interaksional terhadap Keterikatan Karyawan}

Salah satu keadilan yang harus diciptakan adalah keadilan interaksional, yaitu suatu dimensi yang didapatkan melalui interaksi interpersonal maupun informasional ketika menegakkan prosedur/aturan dan membagikan hasilnya (Colquitt, 2001). Alvi dan Abbasi (2012) membuktikan bahwa keadilan organisasi memainkan peran penting dalam mempromosikan karyawan melalui keterlibatan kerja mereka, sehingga kemampuan organisasi dalam berinteraksi harus seimbang dengan apa yang menjadi kinerja mereka. Dalam hal ini, keadilan interaksional meliputi keadilan interpersonal, yaitu karyawan diperlakukan atas dasar asas kesopanan, penghargaan diri, dan rasa hormat oleh para pengambil keputusan organisasi, sedangkan keadilan informasional lebih menekankan pada ketersediaan informasi dan penjelasan mengenai implementasi kebijakan yang diterapkan oleh organisasi. Ketika kedua macam keadilan tersebut dilaksanakan secara seimbang, maka organisasi dapat menghasilkan keterlibatan karyawan yang tinggi. Atas dasar uraian tersebut, rumusan hipotesis keenam (H6) adalah:

\section{H6: Keadilan Interaksional berpengaruh signifikan terhadap Keterikatan Karya- wan.}




\section{Pengaruh Keadilan Distributif terhadap Keterikatan Karyawan melalui Identi- fikasi Organisasional}

Keterikatan karyawan menunjukkan bagaimana individu mencapai kinerja dalam menunaikan pekerjaannya. Lebih lanjut, keterikatan karyawan melibatkan emosi dan perilaku secara aktif yang melibatkan aspek kognitif. Keterikatan karyawan dapat dianggap sebagai anteseden keterlibatan kerja individu, yaitu pengalaman keterikatan peran mereka yang seharusnya muncul untuk mengenal pekerjaan mereka. Keterikatan memperlihatkan bagaimana individu-individu memberdayakan diri mereka sendiri di dalam kinerjanya (Saks, 2006). Dalam hal ini, perilaku secara aktif akan muncul ketika keadilan distributif organisasi diperoleh secara adil dan seimbang, sehingga ketika karyawan menerima upah atau gaji dengan baik dan sesuai beban kerjanya, maka hal itu dianalogikan dapat menciptakan keterikatan karyawan yang didukung oleh identifikasi organisasional. Dari uraian tersebut, hipotesis ketujuh $(\mathrm{H} 7)$ dirumuskan sebagai berikut:

\section{H7: Identifikasi Organisasional memediasi pengaruh Keadilan Distributif terha- dap Keterikatan Karyawan.}

\section{Pengaruh Keadilan Prosedural terhadap Keterikatan Karyawan melalui Iden- tifikasi Organisasional}

Identifikasi organisasional dipandang sebagai sebuah persepsi individu dan persepsi organisasi terhadap keadilan atas reaksi perilaku mereka sebagai sebuah persepsi. Dalam hal ini, dimensi keadilan prosedural mampu mendominasi pengaruhnya pada keterikatan karyawan. Penelitian sebelumnya menunjukkan bahwa seorang karyawan merasakan efek paling signifikan di dalam keterikatan yang diciptakan oleh keadilan organisasional, yaitu keadilan prosedural yang diikuti oleh keadilan distributif dan keadilan interaksional (Özer et al., 2017). Berdasarkan uraian tersebut, hipotesis kedelapan (H8) dirumuskan sebagai berikut:

\section{H8: Identifikasi Organisasional memediasi pengaruh Keadilan Prosedural terha- dap Keterikatan Karyawan.}

\section{Pengaruh antara Keadilan Interaksional dengan Keterikatan Karyawan melalui Identifikasi Organisasional}

Keadilan interaksional merupakan persepsi karyawan tentang tingkatan perlakuan pimpinan organisasi terhadap karyawan dengan martabat, perhatian, dan rasa hormat. Ketika individu diperlakukan tidak adil, maka karyawan akan meresponnya secara negatif. Keadilan interaksional merupakan prediktor terkuat pada kepuasan kerja dibandingkan dengan keadilan yang lain (Al-Khasawneh \& Al-Omari, 2014). Ketika karyawan merasa puas, maka keterikatan dan kebanggaan mereka pada identifikasi organisasional akan terbentuk dengan baik. Hal ini dikarenakan keadilan interaksional lebih merujuk pada sifat interpersonal, yaitu bagaimana hasil keputusan tersebut diimplementasikan (Noe, Hollenbeck, Gerhart, \& Wright, 2011).

\section{H9: Identifikasi Organisasional memediasi pengaruh Keadilan Interaksional ter- hadap Keterikatan Karyawan.}




\section{METODE PENELITIAN}

Obyek penelitian ini adalah PT Permodalan Nasional Madani (Persero) Invesment Management. Jenis penelitian ini adalah penelitian kuantitatif. Teknik penentuan sampel dalam penelitian ini menggunakan total sampling (sensus), yaitu seluruh populasi yang ada atau semua karyawan yang bekerja di PT PNM Invesment Management sebanyak 78 orang sebagai responden. Dari 78 kuesioner yang dibagikan kepada responden, seluruh kuesioner dapat dikumpulkan dan memenuhi syarat untuk diolah, atau response rate sebesar $100 \%$. Melalui kuesioner, responden memberikan tanggapan terkait karakteristik demografi, seperti usia, jenis kelamin, pendidikan terakhir, dan lama bekerja di perusahaan tersebut.

Penelitian ini menggunakan model persamaan struktural (SEM) berbasis varian yang secara simultan dapat melakukan pengujian model pengukuran dan sekaligus menguji model secara struktural. Model pengukuran digunakan untuk uji validitas dan reabilitas, sedangkan model struktural digunakan untuk uji kausalitas (pengujian hipotesis dengan model prediksi). Selanjutnya, Jogiyanto (2011) menyatakan bahwa analisis Partial Least Squares (PLS) adalah teknik statistika multivarian yang dapat melakukan perbandingan antara variabel dependen berganda dan variabel independen berganda. PLS merupakan salah satu metode statistika SEM berbasis varian yang didisain untuk menyelesaikan regresi berganda ketika terjadi permasalahan spesifik pada data penelitian. Selain itu, PLS memiliki kemampuan menganalisis data dengan jumlah sampel kurang dari 100 (Sugiyono, 2017).

\section{Definisi Operasional dan Skala Pengukuran}

Penelitian ini menggunakan tiga variabel independen yang meliputi keadilan distributif (X1), keadilan prosedural (X2), dan keadilan interaksional (X3). Selain itu, penelitian ini menggunakan variabel mediasi (intervening variable), yaitu identifikasi organisasional, serta satu variabel dependen, yaitu keterikatan karyawan. Ada pun indikator yang digunakan merupakan pengembangan dari beberapa teori, yaitu keadilan distributif (Cropanzano et al., 2007) yang terdiri atas tiga butir indikator; keadilan prosedural (Shore \& Shore, 1995) yang berisi enam butir indikator; dan keadilan interaksional (Niehoff \& Moorman, 1993) yang terdiri atas sembilan butir indikator. Selanjutnya, variabel keterikatan karyawan (Schaufeli et al., 2002) yang menggunakan sembilan butir indikator; dan identifikasi organisasional (Mael \& Ashforth, 1992) yang terdiri atas enam butir indikator. Seluruh indikator dikembangkan menjadi kuesioner dengan menggunakan skala pengukuran Likert. Validitas instrumen kuesioner dalam penelitian ini dilakukan evaluasi menggunakan discriminant validity dengan menyimpulkan hasil cross-loading pada setiap indikator pertanyaan yang menyusun variabel (Sugiyono, 2017). Sementara itu, reliabilitas instrumen penelitian ini dievaluasi menggunakan composite reliability yang hasilnya dinyatakan memenuhi standar reliabilitas apabila nilainya lebih dari 0,7 serta memiliki nilai Cronbach's alpha lebih besar dari 0,6 (Jogiyanto, 2011).

\section{Model Penelitian}

Model penelitian pada Gambar 1 didasarkan pada rerangka konseptual yang digunakan dalam penelitian ini yang mencerminkan paradigma sebagai acuan untuk memecahkan masalah penelitian dan menguji hipotesis yang diajukan. Gambar 1 tersebut merupakan model yang akan diuji dalam penelitian ini untuk menggambarkan pengaruh Organizational Justice yang terdiri atas Distributive Justice, Procedural Justice, dan 
Interactional Justice terhadap Employee Engangement melalui mediasi Organizational Identification.

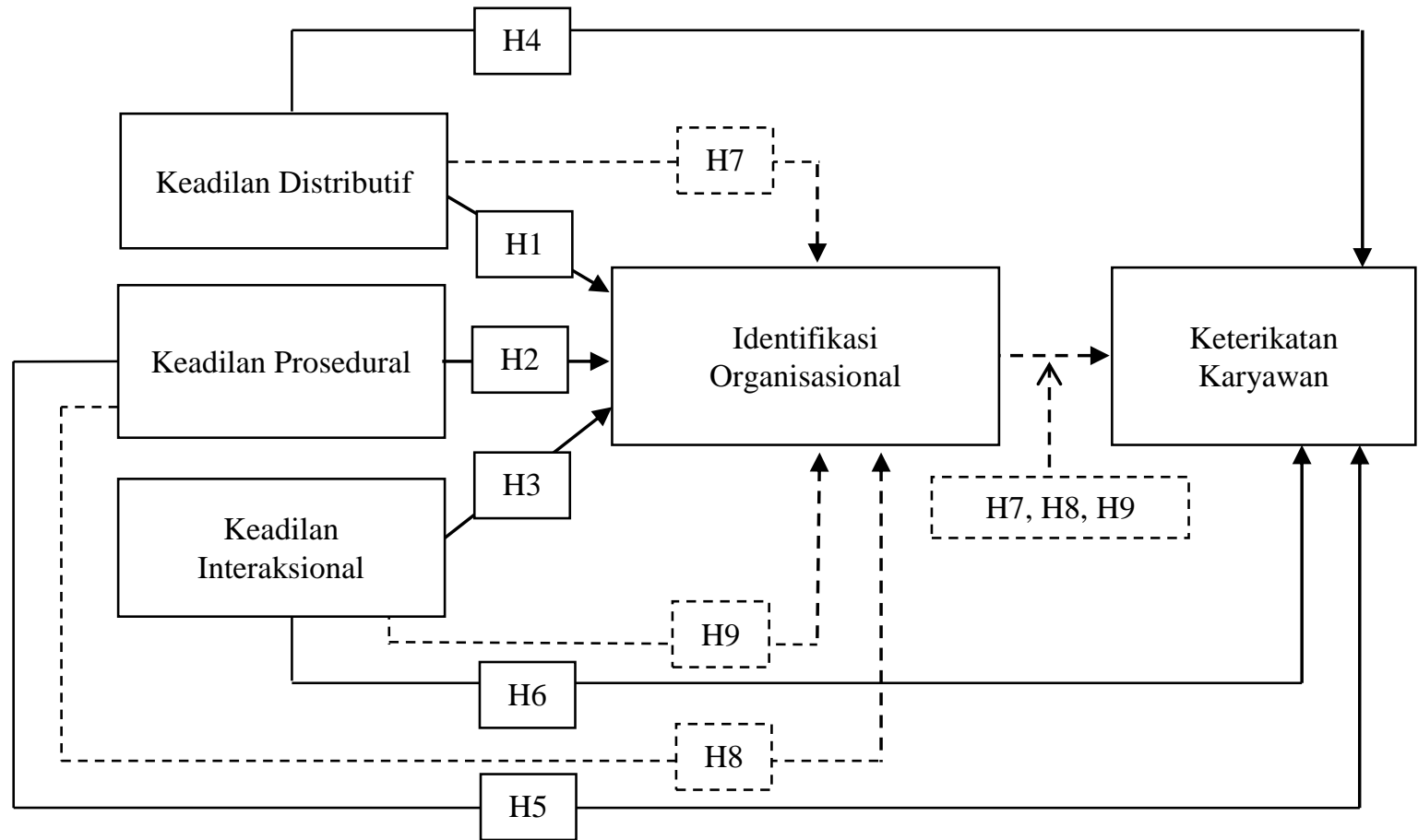

Keterangan:

$\rightarrow=$ pengaruh langsung.

$=$ pengaruh tidak langsung (melalui mediasi).

\section{Gambar 1. Model Penelitian}

\section{HASIL DAN PEMBAHASAN}

\section{Diskripsi Responden}

Identitas responden dalam penelitian sangat penting untuk mengetahui karakteristik responden. Ada pun karakteristik responden yang diidentifikasikan dalam penleitian ini didasarkan pada faktor-faktor demografi meliputi jenis kelamin, divisi kerja, pendidikan terakhir, usia, dan masa kerja responden. Berdasarkan hasil tanggapan responden terhadap kuesioner, maka karakteristik responden diidentifikasi berdasarkan faktorfaktor tersebut.

Berdasarkan jenis kelamin, responden penelitian ini terdiri atas laki-laki dengan jumlah terbesar, yaitu 43 orang atau 55,1\%, sedangkan responden perempuan sebanyak 35 orang atau $44,9 \%$ (Tabel 1). Data ini menunjukkan bahwa mayoritas pegawai perusahaan PT PNM (Persero) adalah laki-laki, karena pekerjaan mereka cenderung lebih banyak dilakukan di lapangan. Tabel 2 menunjukkan bahwa mayoritas dari 78 orang responden bekerja pada Divisi Operations sebanyak 24,4\% atau 19 orang, sedangkan lainnya tersebar di beberapa divisi lain, seperti 13 orang atau 16,7\% masing-masing pada Divisi Investment dan Divisi Marketing, dan responden paling sedikit adalah Direksi yang berjumlah 3 orang atau 3,8\%. Hasil ini menunjukkan bahwa Divisi Operations merupakan bagian dengan jumlah mendominasi, karena kinerja perusahaan ini banyak ditentukan oleh bagian operasional lapangan. 
Tabel 1. Karakteristik Responden Berdasarkan Jenis Kelamin

\begin{tabular}{ccc}
\hline Jenis Kelamin & Jumlah & Persentase \\
\hline Laki-laki & 43 & $55,1 \%$ \\
\hline Perempuan & 35 & $44,9 \%$ \\
\hline Jumlah & $\mathbf{7 8}$ & $\mathbf{1 0 0 , 0 \%}$ \\
\hline
\end{tabular}

Sumber: Pengumpulan data penelitian (2019).

Tabel 2. Karakteristik Responden Berdasarkan Divisi Kerja

\begin{tabular}{lcc}
\hline \multicolumn{1}{c}{ Divisi Kerja } & Jumlah & Persentase \\
\hline Direksi & 3 & $3,8 \%$ \\
\hline Divisi Investment & 13 & $16,7 \%$ \\
\hline Divisi Operations & 19 & $24,4 \%$ \\
\hline Divisi Legal \& Corporate Secretary & 8 & $10,3 \%$ \\
\hline Divisi Product Development \& Management & 10 & $12,8 \%$ \\
\hline Divisi Marketing & 13 & $16,7 \%$ \\
\hline Compliance, Risk Management \& Internal Audit & 4 & $5,1 \%$ \\
\hline Lain- lain & 8 & $10,3 \%$ \\
\hline Jumlah & $\mathbf{7 8}$ & $\mathbf{1 0 0 , 0 \%}$ \\
\hline
\end{tabular}

Sumber: Pengumpulan data penelitian (2019).

Berdasarkan Tabel 3, dari 78 orang responden mayoritas responden berusia antara 30-39 tahun sebanyak 43,6\% dan sisanya adalah karyawan yang berusia antara 20-29 tahun sebanyak 35,9\% dan berusia 40-49 tahun sebanyak 15,4\%.

Tabel 3. Karakteristik Responden Berdasarkan Usia

\begin{tabular}{ccc}
\hline Usia & Jumlah & Persentase \\
\hline $20-29$ tahun & 28 & $35,9 \%$ \\
\hline $30-39$ tahun & 34 & $43,6 \%$ \\
\hline $40-49$ tahun & 12 & $15,4 \%$ \\
\hline >49 tahun & 4 & $5,1 \%$ \\
\hline Jumlah & $\mathbf{7 8}$ & $\mathbf{1 0 0 , 0 \%}$ \\
\hline
\end{tabular}

Sumber: Pengumpulan data penelitian (2019).

Pada Tabel 4, responden penelitian ini mayoritas adalah karyawan dengan tingkat pendidikan terakhir Sarjana (S1) sebanyak 56,4\%. Sisanya yaitu sebanak 16,7\% responden berpendidikan Magister (S2), 15,4\% berpendidikan SMA/SMK, 9\% berpendidikan Diploma (D3), dan hanya 2,6\% yang berpendidikan Doktoral (S3). Hasil ini menunjukkan bahwa Sarjana (S1) adalah pendidikan standar yang mendominasi karyawan perusahaan.

Tabel 4. Karakteristik Responden Berdasarkan Tingkat Pendidikan

\begin{tabular}{crc}
\hline Pendidikan & Jumlah & Persentase \\
\hline SMA/SMK & 12 & $15,4 \%$ \\
\hline Diploma (D3) & 7 & $9,0 \%$ \\
\hline Sarjana (S1) & 44 & $56,4 \%$ \\
\hline Magister (S2) & 13 & $16,7 \%$ \\
\hline Doktoral (S3) & 2 & $2,6 \%$ \\
\hline Jumlah & $\mathbf{7 8}$ & $\mathbf{1 0 0 , 0 \%}$
\end{tabular}

Sumber: Pengumpulan data penelitian (2019). 
Berdasarkan masa kerja (Tabel 5), mayoritas responden memiliki masa kerja 1-5 tahun sebanyak $39,7 \%$ atau sebanyak 31 orang dan responden dengan masa kerja lebih dari 10 tahun merupakan responden dengan jumlah terendah, yaitu 4 orang atau 5,1\%.

Tabel 5. Karakteristik Responden Berdasarkan Masa Kerja

\begin{tabular}{ccc}
\hline Masa Kerja & Jumlah & Persentase \\
\hline$<1$ tahun & 24 & $30,8 \%$ \\
$1-5$ tahun & 31 & $39,7 \%$ \\
$5-10$ tahun & 19 & $24,4 \%$ \\
\hline$>10$ tahun & 4 & $5,1 \%$ \\
\hline Jumlah & $\mathbf{7 8}$ & $\mathbf{1 0 0 , 0 \%}$ \\
\hline
\end{tabular}

Sumber: Pengumpulan data penelitian (2019).

\section{Uji Validitas dan Reliabilitas}

Berdasarkan uji validitas dan reliabilitas, nilai outer loading masing-masing indikator pada semua variabel yang diteliti bernilai lebih besar daripada 0,50. Dengan demikian, indikator-indikator yang digunakan dalam penelitian ini telah memenuhi convergent validity, sedangkan hampir semua nilai korelasi lebih kecil daripada nilai akar AVE (Average Variance Extracted). Hasil tersebut menunjukkan bahwa indikatorindikator di dalam penelitian ini telah memiliki discriminant validity yang baik. Selanjutnya, nilai composite reliability untuk seluruh variabel yang diteliti menunjukkan angka lebih besar dari 0,70. Dengan demikian, masing-masing variabel dalam penelitian ini telah memenuhi composite reliability (Sugiyono, 2017).

\section{Hasil Penelitian}

Hasil penelitian ini menunjukkan bahwa jalur hubungan antara keadilan organisasi terhadap keterikatan karyawan diperoleh nilai $R$-square sebesar 0,964 yang menunjukkan bahwa persentase keragaman persepsi karyawan PT Permodalan Nasional Madani (Persero) Invesment Management (PT PMN) terkait variabel keterikatan karyawan dapat dijelaskan oleh keadilan organisasi sebesar 96,4\%, sedangkan sisanya 3,6\% dijelaskan oleh variabel lain selain keadilan organisasi, sedangkan jalur hubungan dihasilkan nilai $R$-square sebesar 0,924 yang menunjukkan bahwa persentase keragaman persepsi karyawan PT PNM terkait variabel identifikasi organisasional dapat dijelaskan oleh keadilan organisasi sebesar $92,4 \%$, sedangkan sisanya 7,6\% dijelaskan oleh variabel lain selain keadilan organisasi.

Selain nilai $R$-square, analisis SEM dengan PLS juga dapat digunakan untuk menilai koefisien determinasi secara total $\left(R^{2} \mathrm{~m}\right)$. Perhitungan koefisien determinasi total pada model analisis jalur dengan PLS menunjukkan hasil perhitungan dengan nilai koefisien determinasi total sebesar 0,997 yang berarti bahwa model PLS yang dikembangkan mampu menjelaskan variasi keterikatan karyawan dengan faktor keadilan organisasi dan identifikasi organisasional sebesar 99,7\%, sedangkan sisanya sebesar $0,3 \%$ dijelaskan oleh variabel lain yang tidak digunakan di dalam model penelitian ini.

Perhitungan nilai koefisien determinasi total pada model analisis jalur dengan PLS digunakan rumus persamaan [1] sebagai berikut (Sugiyono, 2017):

$$
\mathbf{R}^{2} \mathbf{m}=1-\left(\mathbf{P e 1}^{2} \mathbf{X P e}^{2}\right)
$$


Keterangan pada persamaan [1]:

$\mathrm{R}^{2} \mathrm{~m}=$ Koefisien determinasi total.

$\mathrm{Pei}^{2}=$ Parameter error masing - masing persamaan.

Pei $=\sqrt{1-\mathbf{R t}^{2}}=\left(1-\mathbf{R t}^{2}\right)^{0,5}$

Dari hasil analisis regresi diperoleh nilai $\mathrm{R}^{2}=0,964$ dan nilai $\mathrm{R} 2^{2}=0,924$, sehingga diperoleh nilai

Pe1 dan Pe2 sebagai berikut:

$$
\begin{aligned}
& \text { Pe1 }=(1-0,964) 0,5=0,190 \\
& \text { Pe2 }=(1-0,924) 0,5=0,276
\end{aligned}
$$

Jadi, nilai koefisien determinasi total adalah:

$\mathrm{R}^{2} \mathrm{~m}=1-\left(\mathrm{Pe}^{2} \times \mathrm{Pe}^{2}\right)$

$\mathrm{R}^{2} \mathrm{~m}=1-\left(0,190^{2} \times 0,276^{2}\right)$

$\mathrm{R}^{2} \mathrm{~m}=1-(0,0361 \times 0,0762)$

$R^{2} m=1-(0,00275)$

$\mathbf{R}^{2} \mathbf{m}=\mathbf{1}-0,003=0,997$.

Dari hasil perhitungan didapat nilai koefisien determinasi total sebesar 0,997 yang berarti model PLS yang dikembangkan dapat menjelaskan fenomena mengenai employee engagement dengan faktor organizational justice dan organizational identification sebesar $99,7 \%$, sedangkan sisanya sebesar $0,3 \%$ dijelaskan oleh variabel lain yang tidak digunakan di dalam model penelitian ini.

\section{Uji Hipotesis}

Tabel 6 menunjukkan hasil analisis data pengaruh langsung menggunakan SmartPLS 3.0. Hasil tersebut mendasari pengujian hipotesis H1-H6 yang diajukan dalam penelitian ini. Pada pengujian pengaruh secara langsung tersebut, hasil estimasi pengaruh keadilan distributif terhadap identifikasi organisasional mendapatkan angka koefisien jalur sebesar 0,339 dengan nilai t-statistics 2,975 atau lebih besar daripada 1,96, maka variabel keadilan distributif terbukti memiliki pengaruh signifikan terhadap identifikasi organisasional karyawan PT PMN atau H1 diterima.

Tabel 6. Pengaruh Langsung Variabel Penelitian

\begin{tabular}{lcrrrl}
\hline \multicolumn{1}{c}{ Pengaruh Langsung } & Hipotesis & $\begin{array}{c}\text { Path- } \\
\text { Coefficients }\end{array}$ & $\begin{array}{c}\text { p- } \\
\text { Values }\end{array}$ & $\begin{array}{c}\text { t- } \\
\text { statistic }\end{array}$ & Keterangan \\
\hline $\begin{array}{l}\text { Keadilan Distributif } \rightarrow \text { Identifikasi } \\
\text { Organisasional }\end{array}$ & $\mathrm{H} 1$ & 0,339 & 0,003 & 2,975 & Signifikan \\
\hline $\begin{array}{l}\text { Keadilan Prosedural } \rightarrow \text { Identifikasi } \\
\text { Organisasional }\end{array}$ & $\mathrm{H} 2$ & 0,390 & 0,004 & 2,884 & Signifikan \\
\hline $\begin{array}{l}\text { Keadilan Interaksional } \rightarrow \text { Identifikasi } \\
\text { Organisasional }\end{array}$ & $\mathrm{H} 3$ & 0,265 & 0,023 & 2,276 & Signifikan \\
\hline $\begin{array}{l}\text { Keadilan Distributif } \rightarrow \text { Keterikatan } \\
\text { Karyawan }\end{array}$ & $\mathrm{H} 4$ & 0,114 & 0,106 & 1,621 & $\begin{array}{l}\text { Tidak } \\
\text { Signifikan }\end{array}$ \\
\hline $\begin{array}{l}\text { Keadilan Prosedural } \rightarrow \text { Keterikatan } \\
\text { Karyawan }\end{array}$ & $\mathrm{H} 5$ & 0,692 & 0,000 & 7,179 & Signifikan \\
\hline $\begin{array}{l}\text { Keadilan Interaksional } \rightarrow \text { Keterikatan } \\
\text { Karyawan }\end{array}$ & $\mathrm{H} 6$ & 0,920 & 0,000 & 11,035 & Signifikan \\
\hline Suryan
\end{tabular}

Sumber: Sugiyono (2017).

Hasil tersebut juga menunjukkan estimasi pengaruh keadilan prosedural terhadap identifikasi organisasional dengan koefisien jalur sebesar 0,390 dan nilai t-statistics 
2,884 yang lebih besar daripada 1,96, sehingga hasil tersebut membuktikan bahwa variabel keadilan prosedural berpengaruh signifikan terhadap identifikasi organisasional karyawan PT PMN atau dengan kata lain H2 diterima. Demikian pula, hasil estimasi pengaruh keadilan interaksional terhadap identifikasi organisasional mendapatkan koefisien jalur sebesar 0,265 dengan nilai t-statistics 2,276 atau lebih besar daripada 1,96, maka variabel keadilan interaksional memiliki pengaruh signifikan terhadap identifikasi organisasional para karyawan PT PMN atau H3 diterima.

Hasil estimasi pengaruh keadilan distrbutif terhadap keterikatan karyawan menunjukkan koefisien jalur sebesar 0,114 dengan nilai t-statistics 1,621 atau lebih kecil daripada 1,96. Hasil tersebut menunjukkan bahwa keadilan distributif tidak memiliki pengaruh signifikan terhadap terbentuknya keterikatan karyawan PT PMN yang berarti H4 ditolak. Namun, hasil estimasi pengaruh keadilan prosedural dan keadilan interaksional terhadap keterikatan karyawan menunjukkan bahwa keduanya berpengaruh signifikan terhadap munculnya keterikatan karyawan PT PMN. Dengan koefisien jalur sebesar 0,692 dan nilai $t$-statistics 7,179 pada keadilan prosedural dan koefisien jalur sebesar 0,920 dan nilai $t$-statistics 11,035 pada keadilan interaksional, maka kedua variabel keadilan prosedural dan interaksional memiliki pengaruh signifikan terhadap keterikatan karyawan PT PMN yang berarti H5 dan H6 diterima.

Tabel 7. Pengaruh Langsung dan Pengaruh Tidak Langsung Organizational Justice terhadap Employee Engagement melalui Organizational Identification

\begin{tabular}{lccc}
\hline \multicolumn{1}{c}{ Jalur } & Hipotesis & $\begin{array}{c}\text { Pengaruh } \\
\text { Langsung }\end{array}$ & $\begin{array}{c}\text { Pengaruh Tidak } \\
\text { Langsung }\end{array}$ \\
\hline Keadilan Distributif $\rightarrow$ Keterikatan Karyawan & $\mathrm{H} 4$ & 0,114 & \\
\hline Keadilan Prosedural $\rightarrow$ Keterikatan Karyawan & $\mathrm{H} 5$ & 0,692 & \\
\hline Keadilan Interaksional $\rightarrow$ Keterikatan Karyawan & $\mathrm{H} 6$ & 0,920 & \\
\hline $\begin{array}{l}\text { Keadilan Distributif } \rightarrow \text { Identifikasi } \\
\text { Organisasional } \rightarrow \text { Keterikatan Karyawan }\end{array}$ & $\mathrm{H} 7$ & & $=0,339 \times 0,766=0,259$ \\
\hline $\begin{array}{l}\text { Keadilan Prosedural } \rightarrow \text { Identifikasi } \\
\text { Organisasional } \rightarrow \text { Keterikatan Karyawan }\end{array}$ & $\mathrm{H} 8$ & & $=0,390 \times 0,766=0,299$ \\
\hline $\begin{array}{l}\text { Keadilan Interaksional } \rightarrow \text { Identifikasi } \\
\text { Organisasional } \rightarrow \text { Keterikatan Karyawan }\end{array}$ & $\mathrm{H} 9$ & & $=0,265 \times 0,766=0,203$ \\
\hline
\end{tabular}

Sumber: Sugiyono (2017).

Tabel 7 membuktikan adanya pengaruh tidak langsung keadilan organisasional terhadap keterikatan karyawan melalui mediasi identifikasi organisasional. Hasil estimasi pengujian $\mathrm{H} 7$ menunjukkan nilai 0,259 yang dapat diartikan bahwa secara tidak langsung, identifikasi organisasional mampu memediasi sebesar 25,9\% pengaruh keadilan distributif terhadap keterikatan karyawan PT PMN. Selanjutnya, pengujian H8 menunjukkan nilai estimasi 0,299 yang berarti bahwa secara tidak langsung, identifikasi organisasional mampu memediasi pengaruh keadilan prosedural terhadap keterikatan karyawan PT PMN sebesar 29,9\%, sedangkan pengujian H9 menunjukkan nilai estimasi pengaruh tidak langsung sebesar 0,203 yaitu identifikasi organisasional mampu memediasi pengaruh keadilan interaksional terhadap keterikatan karyawan PT PMN sebesar $20,3 \%$. 


\section{Pembahasan}

Hasil analisis pada hipotesis pertama menunjukkan adanya pengaruh langsung yang signifikan antara distributive justice terhadap organizational identification. Hasil analisis ini senada dengan penelitian Cheung dan Law (2008) bahwa organizational justice, khususnya distributive justice terkait langsung dengan organizational identification. Bagi karyawan yang memiliki tingkat identifikasi organisasional yang tinggi, maka keadilan distibutif yang terkait dengan kompensasi hanyalah hal sederhana yang tidak perlu dipermasalahkan. Bagi karyawan yang memiliki organizational identification tinggi, maka mereka akan berjalan sendiri dengan perasaan keadilan yang dituntut untuk disesuaikan dengan kinerja mereka.

Procedural justice memiliki pengaruh yang signifikan terhadap oganizational identification pada karyawan PT PNM. Hal ini berkaitan dengan prosedur-prosedur yang digunakan oleh organisasi untuk mendistribusikan hasil dan sumber daya organisasi kepada karyawannya. Para karyawan sudah mampu merasakan keadilan prosedural, sehingga mereka dapat menghindari pemikiran negatif di dalam diri mereka sendiri. Procedural justice ini dapat berakibat pada meningkatnya oganizational identification karyawan. Selanjutnya, keadilan prosedural akan menumbuhkan engagement pada diri karyawan dengan pekerjaannya maupun perusahaan tempat mereka bekerja.

Interactional justice memiliki pengaruh signifikan terhadap oganizational identification karyawan PT PNM. Hal ini lebih fokus kepada apakah seseorang merasa diperlakukan adil secara interpersonal atau tidak. Penelitian ini senada dengan penelitian Terzi et al. (2017) yang menyatakan bahwa prediktor kuat organizational identification adalah interactional justice. Penelitian ini menganalisis bahwa keadilan distributif merupakan determinan utama yang mampu dan kuat memprediksi kinerja karyawan. Di sisi lain, keadilan prosedural juga menjadi prediktor employee engagement. Ketika para karyawan memiliki persepsi yang tinggi tentang keadilan di dalam organisasi mereka, maka mereka dapat dipastikan merasa diwajibkan atau diharuskan untuk berlaku adil di dalam memainkan peran mereka dengan memberi lebih besar melampaui tingkat engagement. Hasil penelitian ini juga mendukung penelitian Saks (2006) yang menduga bahwa keadilan prosedural menjadi prediktor terbentuknya employee engagement dalam organisasi. Selain itu, interactional justice juga memiliki pengaruh pada employee engagement.

Hasil analisis dalam penelitian ini menunjukkan bahwa oganizational identification mampu memediasi pengaruh organizational justice, yang terdiri atas distributive justice, procedural justice, dan interactional justice terhadap employee engagement. Hal itu ditunjukkan melalui hasil estimasi pengaruh tidak langsung antara masing-masing dimensi organizational justice terhadap employee engagement melalui organizational identification dengan besaran koefisien tidak langsung yang masih lebih besar dibandingkan dengan pengaruh langsung.

Jogiyanto (2011) mengungkapkan bahwa penting bagi atasan atau pimpinan organisasi untuk melaksanakan proses pengambilan keputusan yang transparan dan sah, serta menyediakan aturan untuk menawarkan kesempatan bagi karyawan menyuarakan pendapat mereka dan ikut berpartisipasi dalam proses pengambilan keputusan kolektif, sehingga hal itu dapat meningkatkan persepsi mereka mengenai procedural justice. Procedural justice ini dapat menyebabkan meningkatnya oganizational identification karyawan dan mampu menumbuhkan engagement pada diri karyawan dengan pekerjaan 
dan perusahaan tempat mereka bekerja. Ketika keputusan dijelaskan dengan baik dan diimplementasikan dengan cara-cara yang peka terhadap kondisi sosial, penuh pertimbangan, dan berempati, maka hasilnya akan terhindar dari kebencian yang dapat muncul dari keputusan pemberhentian kerja. Oleh karena itu, hasil penelitian ini memiliki arti penting untuk mengungkapkan adanya pengaruh tidak langsung antara interactional justice terhadap employee engangement melalui organizational identification.

\section{KESIMPULAN DAN SARAN}

\section{Kesimpulan}

Berdasarkan analisis dan pembahasan yang telah dilakukan, maka kesimpulan yang dihasilkan dari penelitian ini adalah organizational justice yang terdiri atas distributive justice, procedural justice, dan interactional justice mempunyai pengaruh langsung yang signifikan terhadap oganizational identification karyawan PT PNM Investment Management. Dengan demikian, hipotesis kesatu (H1), kedua (H2), dan ketiga (H3) telah terbukti kebenarannya.

Organizational justice yang terdiri atas procedural justice dan interactional justice mempunyai pengaruh langsung yang signifikan terhadap employee engagement karyawan PT PNM Investment Management, sehingga hipotesis kelima (H5) dan keenam (H6) juga terbukti kebenarannya, sedangkan variabel distributive justice tidak memiliki pengaruh langsung yang signifikan terhadap employee engagement karyawan PT PNM Investment Management. Atas dasar hal tersebut, hipotesis keempat (H4) tidak terbukti kebenarannya. Selanjutnya, organizational justice yang terdiri atas distributive justice, procedural justice, dan interactional justice memiliki pengaruh tidak langsung terhadap employee engagement melalui mediasi organizational identification. Hasil ini menunjukkan bahwa komitmen yang dimiliki karyawan mampu dicapai oleh banyak faktor dan beberapa di antaranya berkaitan dengan konsep keadilan perusahaan dan identifikasi organisasi oleh karyawan PT PNM Investment Management.

\section{Saran}

Sesuai hasil analisis penelitian dan pembuktian yang telah dilakukan. maka beberapa saran diajukan dari hasil penelitian ini. Perusahaan diharapkan lebih memantau dan memberikan prioritas kepada karyawan terkait pemberian kompensasi secara adil, sehingga tindakan tersebut lebih dipertimbangkan kembali terkait keadilan distributif yang dirasakan karyawan. Perusahaan juga dapat membuat kebijakan yang lebih mampu melibatkan semakin banyak karyawan, sehingga kebijakan tersebut dapat disosialisasikan secara utuh dan maksimal agar karyawan dapat memahami dengan baik setiap prosedur perusahaan. Perusahaan perlu mempertimbangkan ide atau keberadaan karyawan perusahaan, sehingga setiap keputusan perusahaan dapat mempertimbangkan kondisi karyawan dan memperhatikan kondisi interaksi antarkaryawan maupun karyawan dan perusahaan atau sebaliknya.

Atasan atau pimpinan perusahaan disarankan untuk meluangkan waktu guna mendengarkan setiap permasalahan yang dihadapi karyawan di tempat kerja dan mampu memberikan saran yang tepat untuk menyelesaikannya, sehingga komunikasi dua arah (two-way communication) dapat tercipta dengan baik. Karyawan sebaiknya mampu menyesuaikan diri dalam lingkungan kerja dan memandang seluruh prosedur dan kebijakan perusahaan sebagai motivator untuk bekerja lebih baik lagi. 


\section{DAFTAR REFERENSI}

Ahmed, A., Bwisa, H., Otieno, R., \& Karanja, K. (2014). Strategic Decision Making: Process, Models, and Theories. Business Management and Strategy, 5(1), 78-104. https://doi.org/10.5296/bms.v5i1.5267.

Al-Khasawneh, F. M. S., \& Al-Omari, M. A. (2014). Motivations Towards Learning English: The Case of Jordanian Gifted Students. International Journal of Education, 7(2), 306-321. https://doi.org/10.5296/ije.v7i2.7699.

Alvi, A. K., \& Abbasi, A. S.. (2012). Impact of Organizational Justice on Employee Engagement in Banking Sector of Pakistan. Middle-East Journal of Scientific Research, 12(5), 643-649.

Anitha, J. (2014). Determinants of Employee Engagement and their Impact on Employee Performance. International Journal of Productivity and Performance Management. 63(3), 308-323. https://doi.org/10.1108/IJPPM-01-2013-0008.

Mael, F., \& Ashforth, B. E. (1992). Alumni and Their Almamater: A Partial Test of The Reformulated Model of Organizational. Journal of Organizational Behavior, 13(2), 103-124. https://doi.org/10.1002/job.4030130202.

Herabadi, A. G., Verplanken, B., \& Knippenberg, A. V. (2009). Consumption Experience of Impulse Buying in Indonesia: Emotional Arousal and Hedonistic Considerations. Asian Journal of Social Psychology, 12(1), 20-31. https://doi.org/ 10. 1111/j.1467-839x.2008.01266.x.

Budiarto, Y. \& Wardani, R. P. (2005). Peran Keadilan Distributif, Keadilan Prosedural dan Keadilan Interaksional Perusahaan terhadap Komitmen Karyawan pada Perusahaan. Jurnal Psikologi, 3(2), 109-126.

Cheung, M. F. Y., \& Law, M. C. C. (2008). Relationships of Organizational Justice and Organizational Identification: The Mediating Effects of Perceived Organizational Support in Hong Kong. Asia Pacific Business Review, 14(2), 213-231. https:// doi.org/10.1080/13602380701430879.

Cheney, G., \& Tompkins, P. K. (1987). Coming to Terms with Organizational Identification and Commitment. Central States Speech Journal, 38(1), 1-15. https://doi.org/10.1080/10510978709368225.

Colquitt, J. A. (2001). On the Dimensionality of Organizational Justice: A Construct Validation of Measure. Journal of Applied Psychology, 86(3), 386-400. https:// doi.org/10.1037/0021-9010.86.3.386.

Cropanzano, R., Bowen, D. E., \& Gilliland, S. W. (2007). The Management of Organizational Justice. Academy of Management Perspectives, 21(4), 34-38.

Ghosh, P., Rai, A., \& Sinha, A. (2014). Organizational Justice and Employee Engagement: Exploring the Linkage in Public Sector Banks in India. Personnel Review, 43(4), 628-652. https://doi.org/10.1108/PR-08-2013-0148.

Gibson, J. L., Donnelly, J. H., \& Ivanceivich, J. M. (2009). Organisasi dan Manajemen: Perilaku, Struktur, dan Proses. (Terj.) Joerban Wahid. Jakarta: Penerbit Erlangga.

Gulluce, A. C., \& Kahyaoglu, M. (2016). Correlation between Organizational Justice Perception and Organizational Identification: A Case Study in the Hotels of the Urartu Culture and Tourism Development Region. International Journal of Business Administration, 7(3), 123-131. https://doi.org/10.5430/ijba.v7n3p123. 
Reilly, F. K., \& Brown, K. C. (2012). Investment Analysis \& Portofolio Management. Tenth Edition. Ohio, USA: South-Western Cengage Learning.

Jansen, N. W. H., Kant, I., Nijhuis, F. J. N., Swaen, G. M. H., Kristensen, T. S. (2004). Impact of Worktime Arrangements on Work-home Interference among Dutch Employees. Scandinavian Journal of Environmental Health, 30(2), 139-148.

Jogiyanto, H. M. (2011). Metodologi Penelitian Bisnis: Salah Kaprah dan Pengalamanpengalaman. Yogyakarta: BPFE.

Kreitner, R., \& Kinicki, A. (2007). Perilaku Organisasi. (Terj.) Early Suandy. Jakarta: Salemba Empat.

Konovsky, M. A. (2000). Understanding Procedural Justice and Its Impact on Business Organizations. Journal of Management, 26(3), 489-511. https://doi.org/10.1016/ s0149-2063(00)00042-8.

Macey, W. H., \& Schneider, B. (2008). The Meaning of Employee Engagement. Industrial and Organizational Psychology, 1(1), 3-30.

Niehoff, B. P., \& Moorman, R. H. (1993). Justice as a Mediator of the Relationship between Methods of Monitoring and Organizational Citizenship Behavior. Academy of Management Journal, 36(3), 527-556. https://doi.org/10.2307/ 256591.

Noruzi, M. R., Westover, J. H., \& Rahimi, G. R. (2010). An Exploration of Social Entrepreneusrhip in the Entrepreneurship Era. Asian Social Science, 6(6), 3-10.

Özer, Ö., Uğurluoğlu, Ö., \& Saygili, M. (2017). Effect of Organizational Justice on Work Engagement in Healthcare Sector of Turkey. Journal of Health Management, 19(1), 73-83. https://doi.org/10.1177/0972063416682562.

Pillai, N. V., \& Asalatha, B. P. (2013). Objectivizing the Subjective: Measuring Subjective Wellbeing. Munich Personal RePEc Archive, MPRA Paper No. 45005 (March), 1-40.

Pratt, J. W. \& Zeckhauser, R. (1985). Principals and Agents: The Structure of Business. Boston: Harvard Business School Press.

Noe, R. A., Hollenbeck, J. R., Gerhart, B., Wright, P. M. (2011). Manajemen Sumber Daya Manusia: Mencapai Keunggulan Bersaing. Jakarta: Salemba Empat.

Rhoades, L., \& Eisenberger, R. (2002). Perceived Organizational Support: A Review of the Literature. Journal of Applied Psychology, 87(4), 698-714. https://doi.org/ 10.1037/0021-9010.87.4.698.

Riani, A. L. (2013). Manajemen Sumber Daya Manusia Masa Kini. Yogyakarta: Graha Ilmu.

Robbins, S. P., \& Judge, T. A. (2015). Perilaku Organisasi. Edisi ke-16. (Terj.) Ratna Saraswati \& Febriella Sirait. Jakarta: Salemba Empat.

Saks, A. M. (2006). Antecedents and Consequences of Employee Engagement. Journal of Managerial Psychology, 21(7), 600-619. https://doi.org/10.1108/02683940610 690169.

Schaufeli, W. B., Salanova, M., González-romá, V., \& Bakker, A. B. (2002). The Measurement of Engagement and Burnout: A Two Sample Confirmatory Factor Analytic Approach. Journal of Happiness Studies, 3(1), 71-92. https://doi.org/ 10.1023/a:1015630930326. 
Shore, L. M. \& Shore, T. H. (1995). Perceived Organizational Support and Organizational Justice. Journal of Applied Psychology, 76, 637-643.

Sugiyono, S. (2017). Metode Penelitian Kuantitatif, Kualitatif, dan R\&D. Bandung: CV Alfabeta.

Terzi, A. R., Dülker, A. P., Altın, F., Çelik, F., Dalkiran, M., Yulcu, N. T., Tekin, S., \& Deniz, Ü. (2017). An Analysis of Organizational Justice and Organizational Identification Relation Based on Teachers' Perceptions. Universal Journal of Educational Research, 5(3), 488-495.

Yulianti, P., \& Puteri, E. A. H. (2016). Peran Mediasi Affective Commitment pada Hubungan Procedural Justice, Perceived Organizational Support dengan Employee Engagement. Jurnal Ilmu Ekonomi \& Sosial, 7(1), 14-27. 